\title{
Pulmonary Mycosis associated with Selenium-deficient Cardiomyopathy in Sika Deer
}

\author{
Kazuki YOSHIOKA ${ }^{1)}$, Hideaki UEKI ${ }^{1)}$, Shuiqin $\mathrm{WANG}^{2)}$, Yangxian $\mathrm{LI}^{2)}$, Zhiping XIA ${ }^{2)}$, \\ Hiroyasu YOSHIKAWA ${ }^{1)}$, Toshifumi OYAMADA ${ }^{1)}$ and Takashi YOSHIKAWA ${ }^{1)}$ \\ 1) Department of Veterinary Pathology, Faculty of Veterinary Medicine and Animal Sciences, Kitasato University, \\ 35-1 Higashi 23 Banchou, Towada City, Aomori 034-8628, Japan \\ 2) Department of Veterinary Medicine, Changchung University of Agriculture and Animal Sciences, \\ 175 Xian Road, Changchung, 130062 Jilin Province China \\ (1999.11.9 received, 1999.12.24 accepted)
}

\section{シカのセレニュウム欠乏性心筋症にみられた肺真菌症 \\ 吉岡 一機1), 植木 秀彰1), 王 水 琴2), 李 養 賢2), \\ 夏 志 平 ${ }^{21}$, 吉川 博康 ${ }^{11}$, 小山田 敏文 ${ }^{11}$, 吉川 堯 ${ }^{11}$ \\ 1)北里大学獣医畜産学部獣医病理学講座 $\overline{\mathrm{T}}$ 034-8628 青森県十和田市東二十三番町 35-1 \\ 2)長春農牧大学獣医学院 $\bar{\top} 130062$ 中国吉林長春市西安大路 175}

\begin{abstract}
Pulmonary mycosis of four domestic sika deer (Cervus nippon Temminck and Cervus elaphus) aged 1 to 2 weeks suffering from selenium deficiency (enzootic cardiomyopathy) were examined histopathologically, histochemically and by electron microscopy. From the morphological features of mycosis there were diagnosed aspergillosis in three cases and mucormycosis in one case. The pathologic reaction within lesions of aspergillus were dominated by granulomatous type with neutrophils, macrophages and giant cells, and mucor lesions were remarkable vasculitis with fungal thrombi. It is suggested that the atrophy of lymph follicules and decrease number of $T$ lymphocytes in lymphatic organs is closely correlated with selenium deficiency and immunological disorders.
\end{abstract}

Key Words: cardiomyopathy, mycosis, selenium deficiency, sika deer.

Jpn.J.Zoo Wildl.Med. 5(1) : 87-92, 2000

\section{INTRODUCTION}

A number of papers were published on aspergillosis of the respiratory organs in cattle [1-3], sheep [4] and horses [5-7], but there are few reports of mycotic infection in deer [8-10]. Munro et al. [9] and Jensen et al. [8] are cited that the causal agents of mycotic infection in deer (Cervus elaphus and Dama dama) are stress and intake of mycotical contaminated food. It is also known that majority of mycosis is infected with opportunistically, accompanying basic diseases such as chronic inflammation, leukemia and malignant tumors, or administration of antibiotics and steroid hormones $[3,5,8$, 11-13]. This report describes a pathological study of pulmonary mycosis, associated with selenium deficiency, in farmed sika deer (Cervus nippon Temminck and Cervus elaphus) in the north-east of China (Jilin province). 
Kazuki YoSHIOKA et al.

Table 1 Materials

\begin{tabular}{|c|c|c|c|c|}
\hline CaseNo. & Age(Week) & Sex & Species & Main pathological findings \\
\hline 1 & 1 & $0^{\pi}$ & Cervus nippon Temminck & $\begin{array}{l}\text { Cardiomyopathy } \\
\text { Scatter of caseous nodules in lung } \\
\text { Atrophy of spleen }\end{array}$ \\
\hline 2 & 1 & q & Cervus nippon Temminck & $\begin{array}{l}\text { Cardiomyopathy } \\
\text { Scatter of caseous nodules in lung } \\
\text { Atrophy of spleen }\end{array}$ \\
\hline 3 & 2 & $0^{7}$ & Cervus elaphus & $\begin{array}{l}\text { Cardiomyopathy } \\
\text { Scatter of caseous nodules in lung } \\
\text { Atrophy of spleen }\end{array}$ \\
\hline 4 & 2 & $\sigma^{7}$ & Cervus nippon Temminck & $\begin{array}{l}\text { Cardiomyopathy } \\
\text { Congestion and pulmonary edema } \\
\text { Atrophy of spleen and thymus }\end{array}$ \\
\hline
\end{tabular}

\section{MATERIALS AND METHODS}

The animals are 1 to 2 weeks old four sika deer affected with enzootic cardiomyopathy, as reported previously [14] (Table 1).

\section{Light Microscopy}

Lung specimens were fixed in $10 \%$ buffered formalin without delay, dehydrated in a graded alcohol series, cleared in xylol, and embedded in paraffin wax. Tissue sections of 4 to $6 \mu \mathrm{m}$ thickness were stained by haematoxylin and eosin (HE), periodic acid-Schiff (PAS), Grocott's methenamine silver method (GMS) and Gridley staining for fungi.

\section{Electron Microscopy}

Small blocks of lung were prefixed rapidly in 0.05 M glutaraldehyde, postfixed in 1\% osmic acid and embedded in epoxy resin (Epok 812) by standard procedures. The embedded specimens were sectioned at $1 \mu \mathrm{m}$ thickness and stained in toluidine blue for light microscopical observation. Ultrathin sections were double stained in uranyl acetate and lead citrate staining and observed under a transmission electron microscope (Hitachi $\mathrm{H}-7000$ ).

\section{RESULTS}

\section{Gross Findings}

At autopsy, markedly congestion and purulent catarrhal bronchopneumonia, and in three cases (Case Nos. 1-3), many nodules (1 $\mathrm{mm}$ in diameter) containing caseous or sticky pus were scattered in the lung parenchyma (Fig. 1).

\section{Light Microscopy}

Macroscopic nodules in the lung of Case Nos. 1-3 were characterized by well-demarcated areas of necrosis disposed in stellate fashion. Architectural arrangement of nodules consisted of central areas of necrosis surrounded by zones of cellular infiltration, haemorrhage, and edema. The cellular infiltrates were neutrophils, macrophages and giant cells. Hyphae elements frequently extended beyond the central necrosis into these inflammatory zones.

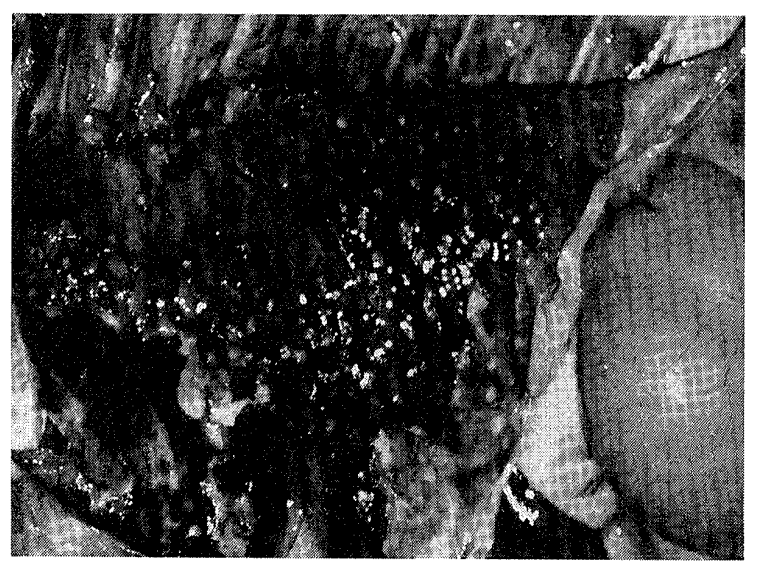

Fig. 1 Gross findings, scatter of many nodules containing caseous or sticky pus in lung. 


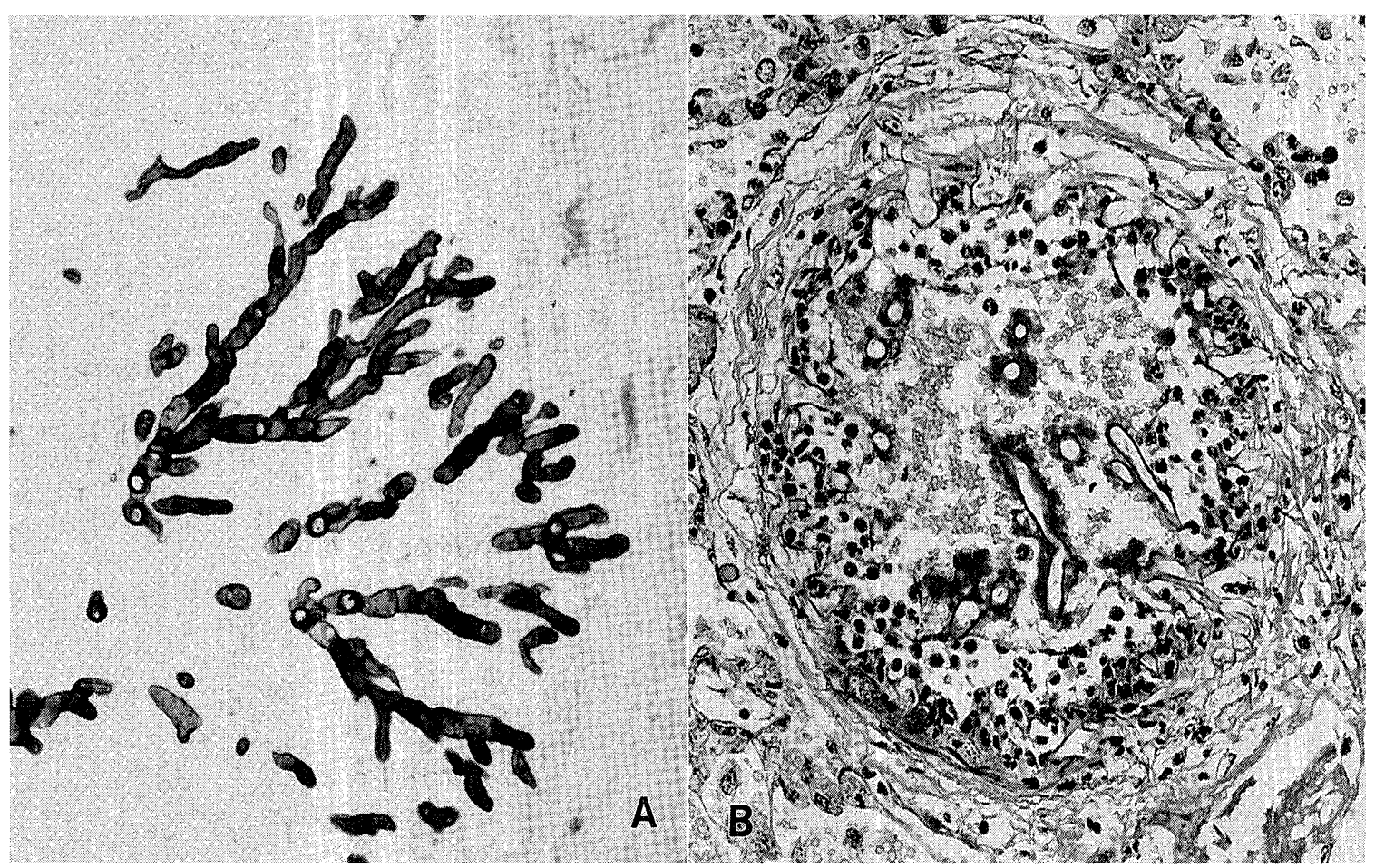

Fig. 2

(A) Aspergillus hyphae, arrangement of a radial pattern. GMS. $\times 560$.

(B) Mucor hyphae, vasculitis with fungal thrombi. PAS. $\times 280$.

Within the central necrosis, numerous PAS and GMS positive hyphae were arranged in a radial pattern (Fig. 2 A). The fungal organism was characterized by 3 to $4 \mu \mathrm{m}$ wide septated hyphae with parallel walls and regular dichotomous branching (Fig. 2 A). These hyphae often proliferated in the terminal bronchi or bronchiole cavities, spreading through the bronchial membrane, smooth muscle and elastic fiber to the surrounding the lung tissue. Occasionally, hyphae arranged in a radial pattern were detected in some blood vessels growing from the wall to the vascular lumen. The reaction of the lymphocytes to granulomatous lesions was either lacking or slight. In another case (Case No.4), on the other hand, the lung lesions in all lobus were congestion and edema, while there was a marked infiltration of neutrophils. At the same time these suppurative changes, vasculitis with fungal thrombi was a frequent observed. A peneterate of the hyphae from the vascular lumen, which caused the vascular lesion, was also observed (Fig. 2 B). The hyphae lacked a septum and their thickness and branching was irregular (Fig. 2 B). They were eosinophilic and reacted positively to PAS and GMS staining but negatively to Gridley staining. No granulomatous reaction to these hyphae was seen. Other points of particular note were atrophy of the follicles in spleen and lymph nodes, and a marked reduction in number of lymphocytes in T-dependent areas (Fig. 3).

\section{Electron Microscopy}

Ultrastructural examination of the hyphae obtained from pulmonary lesions of Case No. 2 . The hyphae showed remarkable thickenings $(0.3$ to $1.3 \mu \mathrm{m}$ ) of the outermost hyphal wall layer. This thickening was composed of poorly differentiated anastomosing microfilaments of reticulate electron dense substance. The innermost hyphae wall layer 


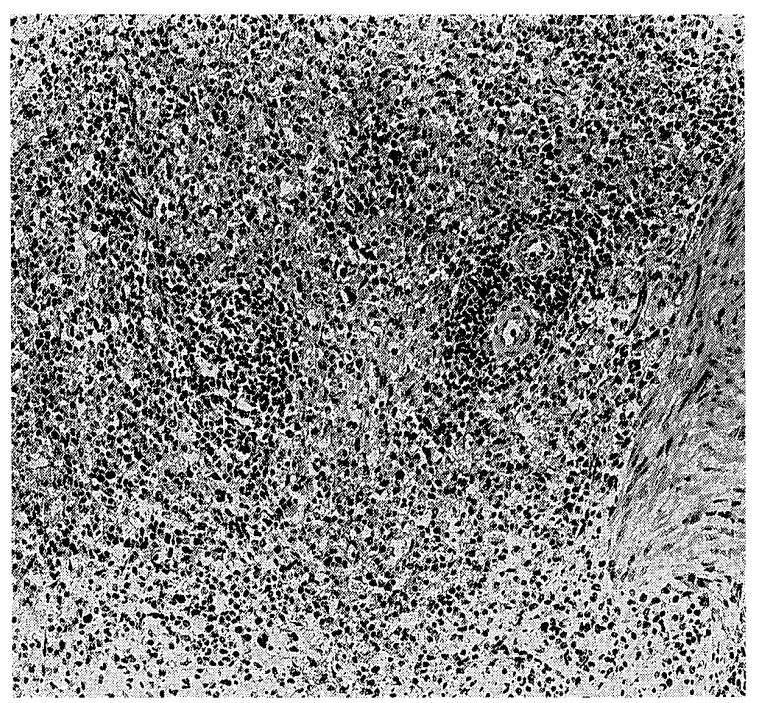

Fig. 3 Atrophy of the follicules in spleen. HE. $\times 100$.

was electron transparent and ranged from 0.3 to 0.6 $\mu \mathrm{m}$ in thickness. Intracytoplasmic organelles were relatively well defined (Fig. 4).

\section{DISCUSSION}

Four cases of pulmonary mycosis of sika deer were described. They were divided into 2 groups according to the type of hyphae. Three cases of aspergillus (Case Nos. 1-3), which had septa, were of almost regular thickness, and showed a characteristic dichotomous branching, and one case of mucor (Case No. 4), which had no septa, irregular thickness, and characteristic proliferation within blood vessels along with thrombus $[2,8,9]$. The granulomas are a characteristic lesion of aspergillosis $[2,8]$, but the spread of inflammation causes from terminal bronchi or bronchiole inflammation which then extent the surrounding tissues.

Ordinary bacterial inflammation processes in the terminal bronchi, bronchiole and alveolar duct, and different from aspergillus pneumonia [15]. Gowing and Hamlin [12] suggested that the necrosis and vascular damage seen in Hodgkin's disease and leukemia infected with Aspergillus fumigatus is due to

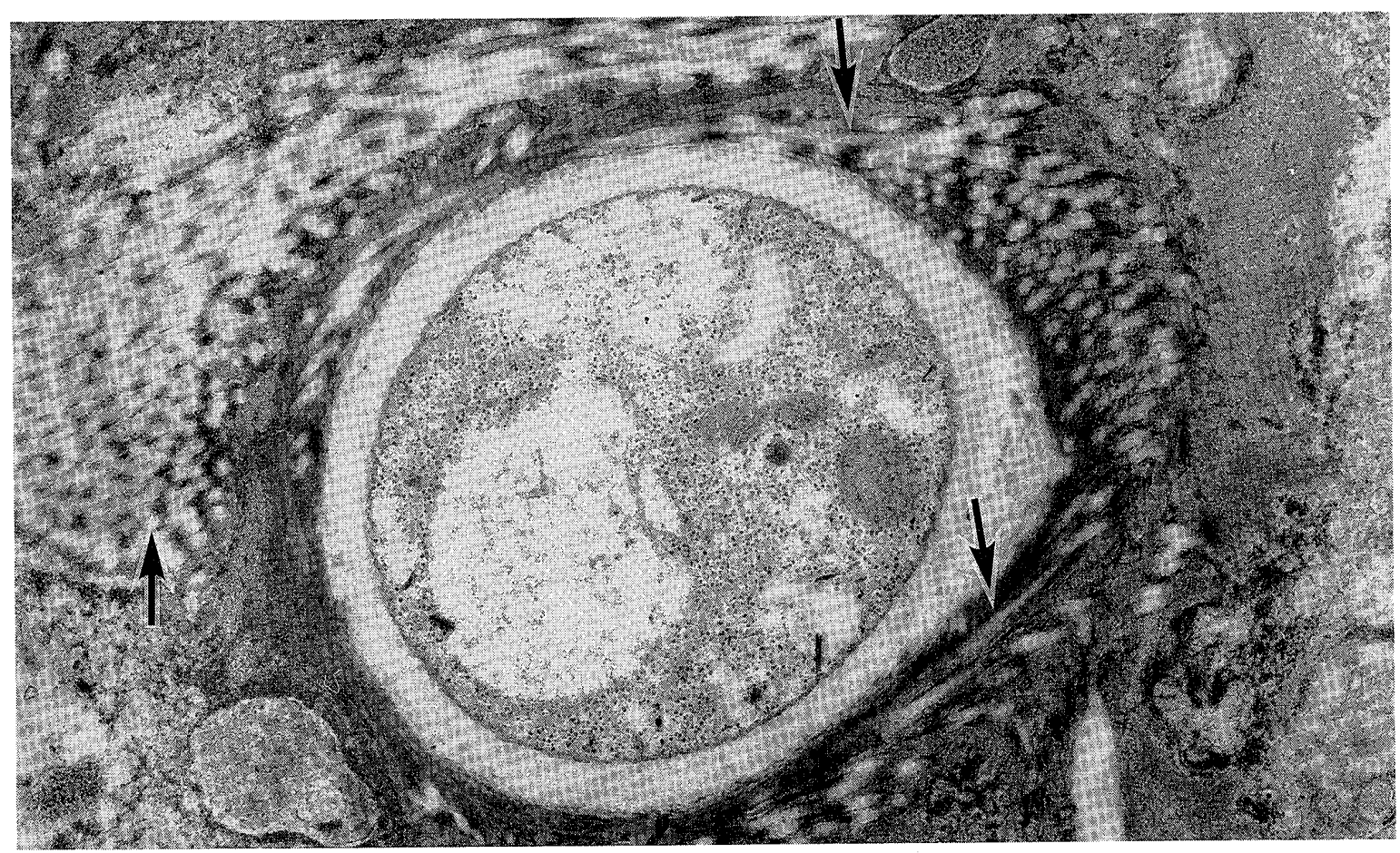

Fig. 4 The outermost hyphal wall of aspergillus composed of poorly differenciated anastomosing microfilaments (arrow) of reticulate electron dense substance. $\times 20000$. 
the diffusible toxic metabolites produced by hyphae. Kothary et al. [16] reported that the elastase produced from aspergillus play a role in its inva. sion, and experiments by Yokota et al. [17] on the effect of Asp-hemolysin produced by aspergillus on mice showed necrosis in cardiac muscles and liver cells, suggesting that Asp-hemolysin might play a role in the development of the mycotic infection.

The vasculitis and destruction of elastic fibers seen in alveolar wall, and microfibrils observed in ultrastructure of hyphae suggest the participate of a toxic substance produced by aspergillus. Sukroongreung and Thakerngpol [18] state that the microfibrillar material is a true extracellular component. Various factors are given for the emergence of mycotic infection [11, 13]. The important factors are immunological condition and the existence of any basic disease.

All the cases we examined were less than 2 weeks old, and they suffered from myocardial disease. Myocardial disease in deer, which occurs in the northeastern part of China, is similar in nature to a human disease in the same region called Keshan disease, and its correlation with selenium deficiency is strongly doubted from its epidemiological background and pathological characteristics [14, 19-21]. Taylor [22] suggests that, since messenger RNA with $T$ lymphocyte-related genes (CD 4, CD 8 and HLA-DRp 33) has the open reading frame that codes for selenoprotein, selenium is essential for the proliferation of lymphocytes, and a deficiency in selenium leads to a reduction in lymphocyte and impaired immunofunction.

Kukreja and Khan [23] reported atrophy and T lymphocyte reduction in the spleen and thymus in experimental selenium-deficient rats. The atrophy and particularly the reduction in $\mathrm{T}$-dependent area of the lymphatic organs seen in all the cases examined suggest a correlation with immuno-depression and selenium deficiency.

\begin{abstract}
要 約
セレニュウム欠乏性心筋症に罹患した 1～2 週齢の梅花 鹿(Cervus nippon Temminck) 3 例および馬鹿 (Cervus elaphus) 1 例, 計 4 例の肺真菌症について病理形態学的に 検討した。菌系の形態から Aspergillus 症(3 例), Mucor 症 (1 例) と診断され, 前者は肉芽腫性病巣, 後者は血栓を伴う 脈管炎が特徵的であった。真菌感染の成立に対し，検索例 で共通的に認められたリンパ系器官の萎縮, 特に Tリンパ 球の減少およびセレニュウム久乏と免疫機序との関連が示 唆された。

キーワード：心筋症, 真菌症, セレニュウム欠乏, 鹿
\end{abstract}

\section{REFERENCES}

1. Austwick PKC. 1962. The presence of Aspergillus fumigatus in the lungs of dairy cows. Lab Invest 11: 1065-1072.

2. Chihaya Y, Furusawa Y, Okada H, Matsukawa K, Matsui Y. 1991. Pathological studies on systemic mycoses in calves. J Vet Med Sci 53: 1051-1058.

3. Chihaya Y, Okada H, Matsukawa K, Matsui Y. 1992. Disseminated mycoses in cattle. A study on nine autopsy cases. $J$ Vet Med Sci 54: 485-491.

4. Perez V, Corpa JM, Garcia Marin JF, Aduriz JJ, Jensen HE. 1998. Mammary and systemic aspergillosis in dairy sheep. Vet Pathol 35: 235-240.

5. Carrasco L, Tarradas MC, Gomez-Villamandos JC, Luque I, Arenas A, Mendez A. 1997. Equine pulmonary mycosis due to Aspergillus niger and Rhizopus stolonifer. J Comp Pathol 117: 191-199.

6. Hattel AL, Drake TR, Anderholm BJ, McAllister ES. 1991. Pulmonary aspergillosis associated with acute enteritis in a horse. J Am Vet Med Assoc 199: 589-590.

7. Slocombe RF, Slauson DO. 1988. Invasive pulmonary aspergillosis of horses: An association with acute enteritis. Vet Pathol 25: $277-281$.

8. Jensen HE, Jorgensen JB, Schonheyder H. 1989. Pulmonary mycosis in farmed deer: Allergic zygomycosis and invasive aspergillosis. J Med Vet Mycol 27: 329-334.

9. Munro R, Hunter AR, Bonniwell M, Corrigall W. 1984. Systemic mycosis in Scottish red deer (Cervus elaphus). I Comp Pathol 95: 281-289.

10. Sato Y, Matsuura S. 1998. Gastric mucormycosis in a sika deer (Cervus nippon) associated with proliferation of Clostridium perfringens. J Vet Med Sci 60: 981-983.

11. Conesa D, Rello J, Valles J, Mariscal D, Ferreres JC. 1995. Invasive aspergillosis: A life-threatening complication of short -term steroid treatment. Ann Pharmacother 29: 1235-1237. 


\section{Kazuki YOSHIOKA et al.}

12. Gowing VFC, Hamlin IME. 1960. Tissue reactions of aspergillus in cases of Hodgkin's disease and leukemia. J Clin Pathol 13: 396-413.

13. Meyer RD, Rosen P, Armstrong D. 1972. Phycomycosis complicating leukemia and lymphoma. Ann Intern Med 77: 871-879.

14. Yoshioka K, Ueki H, Kurotaki T, Oyamada T, Yoshikawa H, Yoshikawa T, Wang S, Li Y, Xia Z. 2000. Myocardial lesions of enzootic cardiomyopathy in sika deer (Cervus nippon Temminck). J Jpn Vet Med Assoc 53: 101-104.

15. Kobzik L, Schoen FJ. 1994. The Lung. In Robbins pathologic basis of disease, 5 th Edit. (Cotran RS, Robbins SL, Kumar V eds.), pp. 673-734. W. B. Saunders Company, Philadelphia.

16. Kothary MH, Chase Jr.T, Macmillan JD. 1984. Correlation of elastase production by some strains of Aspergillus fumigatus with ability to cause pulmonary invasive aspergillosis in mice. Infect Immun 43: 320-325.

17. Yokota K, Shimada H, Kamaguchi A, Sakaguchi O. 1977. Studies on the toxin of Aspergillus fumigatus, VII. Purification and some properties of hemolytic toxin (Asp-hemolysin) from culture filtrates and mycelia. Microbiol Immunol 21: 11-22.

18. Sukroongreung S, Thakerngpol K. 1985. Abnormal form of Aspergillus terreus isolated from mycotic abscesses. Mycopathologia 91: 47-52.

19. Bo-qi G. 1983. Pathology of Keshan disease: A comprehensive review. Chin Med J 96: 251-261.

20. Ge K, Xue A, Bai J, Wang S. 1983. Keshan disease an endemic cardiomyopathy in China. Virchows Arch A Pathol Anat Histopathol 401: 1-15.

21. Li G, Wang F, Kang D, Li C. 1985. Keshan disease: An endemic cardiomyopathy in China. Hum Pathol 16: 602-609.

22. Taylar EW. 1995. Selenium and cellular immunity: Evidence that selenoproteins may be encoded in the +1 reading frame overlapping the human $\mathrm{CD} 4, \mathrm{CD} 8$, and HLA-DR genes. Biol Trace Elem Res 49: 85-95.

23. Kukreja, R, Khan A. 1997. Effect of experimental selenium deficiency and its supplementation on lymphoid organs. Indian $J$ Exp Biol 35: 952-956. 